Original Research Paper

\title{
Improving Effects of Different Calcium-Magnesium Conditioners on Latosol
}

\author{
${ }^{1} \mathrm{Jin} \mathrm{Li},{ }^{1}$ Yingbin Xue, ${ }^{2}$ Minzhong Chen, ${ }^{2}$ Huirong Su, ${ }^{1}$ Zhengwei Wu and ${ }^{1{ }^{*}}$ Tingting Duan \\ ${ }^{1}$ Guangdong Ocean University, Zhanjiang, 524088, China \\ ${ }^{2}$ Zhanjiang Agricultural Technology and Popularization Center, Zhanjiang, 524000, China
}

\author{
Article history \\ Received: $10-08-2020$ \\ Revised: 10-10-2020 \\ Accepted: 12-10-2020 \\ Corresponding Author: \\ Tingting Duan \\ Guangdong Ocean University, \\ Zhanjiang, 524088, China \\ Email: duan_1257@126.com
}

\begin{abstract}
At present, soil acidification seriously restricts the sustainable development of agricultural production. A common method that can be used to improve acidified soils is to apply calcareous materials (conditioners), but there is difference in the improvement effect of the conditioners on the same soil because of the conditioners containing different calcium-magnesium compounds. In order to find suitable conditioners for latosol (acidic red soil), two consecutive soil incubation experiments in laboratory have be done to study the improvement effects of different calcium-magnesium compounds on latosol. The results showed that: (1) Self-made conditioner (CM and it is composed of $\left.\mathrm{Mg}(\mathrm{OH})_{2}, \mathrm{Ca}(\mathrm{OH})_{2}, \mathrm{MgCl}_{2}, \mathrm{CaCl}_{2}\right), \mathrm{CaO}, \mathrm{CaCO}_{3}$ and $\mathrm{Mg}(\mathrm{OH})_{2}$ could rapidly increase the $\mathrm{pH}$ and significantly reduce the content of potential acid in latosol. The soil exchangeable acid of $\mathrm{Mg}(\mathrm{OH})_{2}$, $\mathrm{CaCO}_{3}, \mathrm{CaO}$ and $\mathrm{CM}$ treatments than the treatment without conditioner (CK) were reduced by $88,72,66$ and $34 \%$, respectively, and the soil exchangeable aluminum decreased by $91,80,71$ and $58 \%$, respectively. (2) The calcium-magnesium compounds can significantly increase the contents of soluble and exchangeable calcium in soil compared with CK. CM and $\mathrm{Mg}(\mathrm{OH})_{2}$ significantly increased the contents of soluble and exchangeable magnesium in latosol. (3) The soil $\mathrm{pH}$ buffer capacity of $\mathrm{CM}$ is significantly higher than those of other treatments as a result of it has the highest organic matter content and significantly increases the contents of exchangeable calcium and magnesium in the soil. But the soil $\mathrm{pH}$ buffer capacity of $\mathrm{CaCO}_{3}$ and $\mathrm{Mg}(\mathrm{OH})_{2}$ are significantly less than that of CK. Because the organic matter and organic acid of $\mathrm{CaCO}_{3}$ and $\mathrm{Mg}(\mathrm{OH})_{2}$ treatments are reduced by the soil $\mathrm{pH}$ of them increasing and the functional groups with $\mathrm{pH}$ buffer capacity on them may also be destroyed. So the paper suggests that improve acid latosol by applying conditioners with more soluble calcium and magnesium, $\mathrm{Mg}(\mathrm{OH})_{2}$, which can effectively reduce acid ions in soil and improve the $\mathrm{pH}$ buffer capacity of soil.
\end{abstract}

Keywords: Latosol, Soil Conditioners, Exchangeable $\mathrm{Ca}$ and $\mathrm{Mg}, \mathrm{pH}$ Buffer Capacity

\section{Introduction}

At present, the problem of soil acidification caused by factors such as climate, acid rain, long-term application of chemical fertilizer, etc., seriously restricts the sustainable development of agricultural production. According to statistics, acid soil accounts for $40 \%$ of the total area of cultivated land in the world (Teutscherova et al., 2017) and is $21 \%$ of the total cultivated land area in China and the acidified soil area is increasing. Soil acidification has become an issue of global agriculture (Guo et al., 2010). The main reason for soil acidification is that many base ions such as calcium and magnesium in the soil had leached loss, resulting in the release of acid ions such as hydrogen and aluminum ions. Soil acidification can lead to a series of problems such as soil nutrient imbalance, soil compaction and soil fertility decline, which are bad for crop growth and development (Lu et al., 2014).

At present, in the domestic and foreign research on soil acidity improvement, the commonly used method is to control the soil acidification by applying alkaline 
conditioners with calcium and magnesium (Antonangelo et al., 2017). The application of alkaline conditioners can effectively increase the $\mathrm{pH}$ of acidic soil in a short time and can neutralize the potential acid, reduce the exchangeable acid ion in acid soil, while supplement the calcium and magnesium in acidic soil. Commonly used calcareous materials that can be used to improve acidified soil are mainly alkaline materials with calcium and magnesium such as quicklime $(\mathrm{CaO})$, slaked lime $\left(\mathrm{Ca}(\mathrm{OH})_{2}\right)$, limestone $\left(\mathrm{CaCO}_{3}\right)$, dolomite powder $\left(\mathrm{CaMg}\left(\mathrm{CO}_{3}\right)_{2}\right)$, industrial and mining byproducts $\left(\mathrm{MgO}, \mathrm{CaO}, \mathrm{Ca}(\mathrm{OH})_{2}, \mathrm{Mg}(\mathrm{OH})_{2}, \mathrm{CaCO}_{3}\right.$ and $\mathrm{MgCO}_{3}$ ) (Lollato et al., 2013). The reason that all kinds of calcareous materials can improve acidic soil is mainly because it contains a large amount of calciummagnesium alkaline compounds, but the acidity improvement effect on the same soil is different because of each material contains different calcium-magnesium compounds (Illera et al., 2004). Therefore, it is important to study the improvement effect of different alkaline calcium-magnesium compounds on acidic soils, which is essential for the production or selection of calcareous conditioners with high-quality calcium-magnesium compounds to improved acidified soil, which can effectively improve acidic soils and is of great significance to sustainable development of agricultural production at the same time.

In this study, the self-made calcium-magnesium conditioner, calcium oxide, calcium carbonate and magnesium hydroxide were used as research objects. The method of soil incubation in laboratory was used to study the improvement effect of different alkaline calcium-magnesium compounds on latosol in order to find the suitable calcareous conditioner for latosol and reduce soil acidity and provide a theoretical basis for the improvement and sustainable use of latosol.

\section{Materials and Methods}

\section{Test Soil}

The test soil was taken from ploughed soil with the thickness of $0-20 \mathrm{~cm}\left(21^{\circ} 9^{\prime} 15^{\prime \prime} \mathrm{N}, 110^{\circ} 17^{\prime} 30^{\prime \prime} \mathrm{E}\right)$ of sugar cane land in Waihuan West Road, Guangdong Ocean University, Zhanjiang City, Guangdong Province, China. The soil is a typical acid latosol derived from basalt in the Leizhou Peninsula. The soil samples were naturally air-dried, ground and sieved through 2 and $0.149 \mathrm{~mm}$, respectively for soil incubation tests and for determination of basic physical and chemical values of soil. The basic physical and chemical properties of the tested soil (Initial soil) are as follows: pH 4.29, EC 0.71, total nitrogen $0.41 \mathrm{~g} / \mathrm{kg}$, available nitrogen $64.62 \mathrm{mg} / \mathrm{kg}$, available phosphorus $17.48 \mathrm{mg} / \mathrm{kg}$, available potassium $117.10 \mathrm{mg} / \mathrm{kg}$, organic matter $21.12 \mathrm{~g} / \mathrm{kg}$, exchangeable calcium $3.25 \mathrm{cmol} / \mathrm{kg}$, exchangeable magnesium 1.56 $\mathrm{cmol} / \mathrm{kg}$, soluble calcium $0.11 \mathrm{cmol} / \mathrm{kg}$, soluble magnesium $0.21 \mathrm{cmol} / \mathrm{kg}$, exchangeable acid 3.06 $\mathrm{cmol} / \mathrm{kg}$, exchangeable ammonium $2.40 \mathrm{cmol} / \mathrm{kg}, \mathrm{pH}$ buffer capacity $33.86 \mathrm{mmol} / \mathrm{kg}$.

\section{Test Soil Conditioner}

The self-made Calcium-Magnesium conditioner (CM) used in this study is a calcium-magnesium alkaline compound produced by seawater as raw material through resins and inputting lime precipitation method (Li et al., 2019). Its main component is $\mathrm{Mg}(\mathrm{OH})_{2}, \mathrm{Ca}(\mathrm{OH})_{2}, \mathrm{MgCl}_{2}, \mathrm{CaCl}_{2}$, other components and the percentage of the weight of each component is $12,23,3,60$ and $2 \%$, respectively.

The test calcium oxide is an analytically pure $\mathrm{CaO}$ drug (AR), calcium carbonate is an analytically pure $\mathrm{CaCO}_{3}$ drug (AR) and magnesium hydroxide is an analytically pure $\mathrm{Mg}(\mathrm{OH})_{2}$ drug (AR). The basic physical and chemical properties of the test soil conditioners are shown in Table 1.

\section{Experimental Design}

The experimental site of this study is the third experimental building of Guangdong Ocean University, Zhanjiang, Guangdong, China, located at latitude of $21^{\circ} 8^{\prime} \mathrm{N}$ and a longitude of $110^{\circ} 17^{\prime} \mathrm{E}$. The soil incubation method is adopted. The incubation time is from October 2018 to December 2018, from December 2018 to February 2019 for two consecutive experiments. Each incubation box was filled with $2 \mathrm{~kg}$ of soil and the four types of soil conditioners were respectively placed in the incubation box with stirring well and total amount of pure calcium and magnesium in each conditioner added to the soil was calculated to correspond to $0.09 \%$ of the soil mass, that is, Calcium-Magnesium conditioner (CM), $\mathrm{CaO}, \mathrm{CaCO}_{3}, \mathrm{Mg}(\mathrm{OH})_{2}$, four treatments were set and another blank control (CK) without added conditioner was set. Five treatments in total, three replicates per treatment, a total of 15 replicates.

Table 1: Basic physicochemical property of conditioners for testing

\begin{tabular}{lrrrr}
\hline Conditioners & \multicolumn{1}{c}{$\mathrm{CM}$} & $\mathrm{CaO}$ & $\mathrm{CaCO}_{3}$ & $\mathrm{Mg}(\mathrm{OH})_{2}$ \\
\hline $\mathrm{pH}$ & 11.15 & 12.15 & 8.54 & 10.23 \\
$\mathrm{EC}(\mathrm{ms} / \mathrm{cm})$ & 172.35 & 55.50 & 8.44 & 3.80 \\
Purity $(\%)$ & 98.00 & 98.00 & 99.00 & 95.00 \\
Soluble calcium $(\mathrm{g} / \mathrm{kg})$ & 239.04 & 3.82 & 0.21 & 0.03 \\
Soluble magnesium $(\mathrm{g} / \mathrm{kg})$ & 7.67 & 0.01 & 0.01 & 0.42 \\
\hline
\end{tabular}




\section{Soil Samples Collection and Samples Analysis}

Regularly added water and kept the soil water content at $70 \%$ of the field moisture capacity. After adding water, stirring well to make it uniform, putting it into the MGC$450 \mathrm{HP}-2$ artificial climate chamber, set the temperature to $26^{\circ} \mathrm{C}$ and incubated at the humidity of $60 \%$ for 56 days. Soil samples were taken on days 1, 2, 6, 12, 26, 41 and 56 of the incubation and 2 soil samples were taken from each box, that is, 6 replicate soil samples were taken for each treatment.

Soil $\mathrm{pH}$ was measured by laboratory $\mathrm{pH}$ meter (PHSJ3F), soil EC value was measured by conductivity meter (DDSJ-308A conductivity meter), exchangeable acidity and ammonium (Al) were measured by potassium chloride-titration method (Bao, 2010), pH buffer capacity was measured by $\mathrm{pH}$ titration and buffering curve (Bao, 2010), soil exchangeable calcium and magnesium ions were measured by extracting with ammonium acetateatomic absorption spectroscopy method (Hitachi, ZA3000, AAS) (Seeger et al., 2019), the soil organic carbon was measured by extracting soil samples with $\mathrm{K}_{2} \mathrm{Cr}_{2} \mathrm{O}_{7}$ and $\mathrm{H}_{2} \mathrm{SO}_{4}$-titration with standardized $\mathrm{FeSO}_{4}$ (Fu et al., 2010), total nitrogen was measured by the Kjeldahl method (Fu et al., 2010), available nitrogen in soil was determined by automated colorimetric methods after extraction with $2 \mathrm{M} \mathrm{KCl}$ (Takeda et al., 2020), molybdenum-antimony colorimetry (UV-1100 ultraviolet spectrophotometer) for the measurement of available phosphorus (Bao, 2010), ammonium acetate-flame photometric method (FP6431 flame photometer) for the measurement of available potassium (Bao, 2010).

\section{Data Statistical Analysis Method}

Each experiment consisted of three replicates (six replicate samples) per treatment. Data were analyzed as means of two consecutive experiments (October 2018December 2018, December 2018-February 2019) and the differences among treatments were computed using Duncan's multiple range test at $\mathrm{p}=0.05$. All data analysis and statistics were performed using SPSS18.0 and Microsoft Excel 2010.

\section{Results and Discussion}

\section{Effects of Different Calcium-Magnesium Conditioners on the pH of Soil}

It can be seen from the results in Fig. 1 that the soil $\mathrm{pH}$ values of the four calcium-magnesium conditioners were much higher than those of CK treatment and the difference between treatments was significant. The soil $\mathrm{pH}$ order of each treatment was $\mathrm{Mg}(\mathrm{OH})_{2}>\mathrm{CaCO}_{3}>$ $\mathrm{CaO}>\mathrm{CM}>\mathrm{CK}$. It can also be seen from Fig. 1 that during the 56-day incubation period, the soil $\mathrm{pH}$ of $\mathrm{CK}$ and the $\mathrm{pH}$ of the initial soil (4.29) are basically the same and the change is not obvious and the $\mathrm{pH}$ of added four calcium-magnesium conditioners rose rapidly at the first day and then stabilized. This indicates that the application of $\mathrm{CM}, \mathrm{CaO}, \mathrm{CaCO}_{3}$, $\mathrm{Mg}(\mathrm{OH})_{2}$ can rapidly increase the $\mathrm{pH}$ of the acidic soil, especially the $\mathrm{Mg}(\mathrm{OH})_{2}$ treatment and the soil $\mathrm{pH}$ is increased by more than one unit during the whole incubation period. This may be because the different calcium-magnesium compounds are alkaline materials and the $\mathrm{OH}^{-}$formed after added it to the soil neutralizes the active acid $\mathrm{H}^{+}$in the soil solution, so the $\mathrm{pH}$ is increased. Probably because $\mathrm{Mg}(\mathrm{OH})_{2}$ contains $\mathrm{OH}^{-}$, $\mathrm{OH}^{-}$itself, which can react directly with active acid in the soil, so $\mathrm{Mg}(\mathrm{OH})_{2}$ has the most significant effect on increasing the $\mathrm{pH}$ of soil.

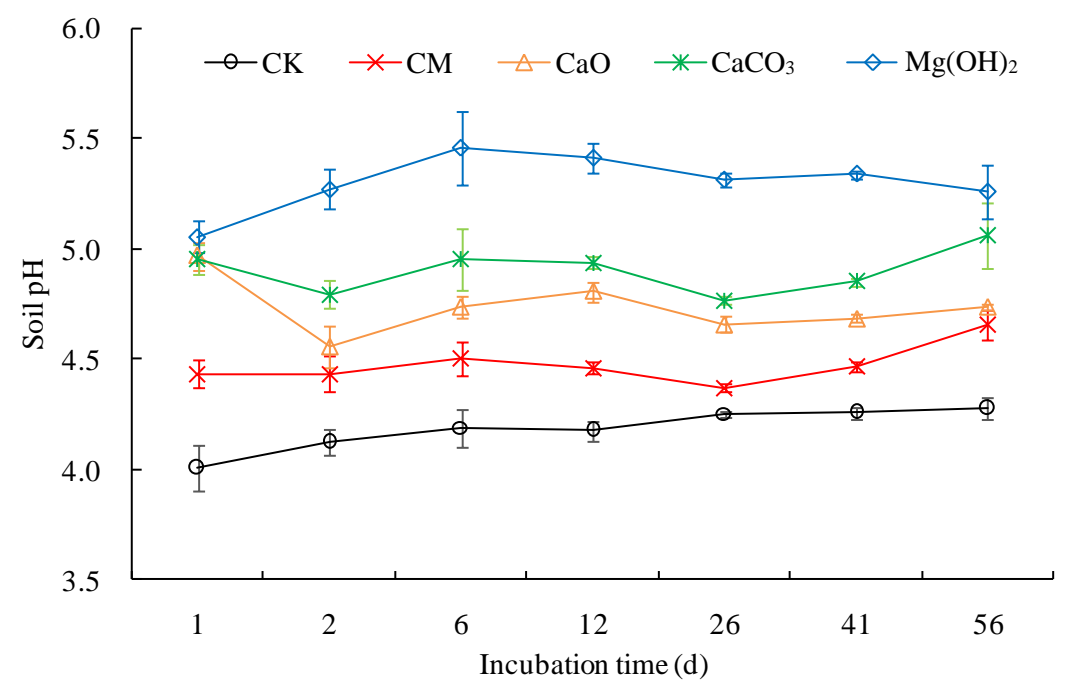

Fig. 1: Effects of different conditioners on soil $\mathrm{pH}$ 
Effects of Different Calcium-Magnesium Conditioners on Soil Exchangeable Acid and Exchangeable Aluminum

In acidic mineral soils, the active acid (soil $\mathrm{pH}$ ) is mainly derived from soil potential acids, i.e., soil exchangeable acid ions $\left(\mathrm{H}^{+}\right.$and $\left.\mathrm{Al}^{3+}\right)$. Generally soil $\mathrm{pH}$ is negatively related to soil exchangeable acidity $\left(\mathrm{H}^{+}\right.$and $\mathrm{Al}^{3+}$ ). Especially three units $\mathrm{H}^{+}$are produced after one unit $\mathrm{Al}^{3+}$ hydrolysis $\left(\mathrm{Al}^{3+}+3 \mathrm{H}_{2} \mathrm{O}=\mathrm{Al}(\mathrm{OH})_{3}+3 \mathrm{H}^{+}\right)$, which is the main cause of low $\mathrm{pH}$ in acidified soil and activity of $\mathrm{Al}^{3+}$ is strong and plants are easily affected by aluminum toxicity (Elisa et al., 2015). Therefore, the study of exchangeable acidity and exchangeable $\mathrm{Al}^{3+}$ in soil is an important reference indicator for determining improvement effects of acid soil with the conditioners.
As shown in Fig. 2, the soil exchangeable acidity without adding soil conditioner (CK) remained substantially above $3 \mathrm{cmol} / \mathrm{kg}$ throughout the incubation period and the exchangeable acidity increased with the prolongation of the incubation time. When the soil conditioners was applied, the content of soil exchangeable acid decreased and those of $\operatorname{Mg}(\mathrm{OH})_{2}$, $\mathrm{CaCO}_{3}, \mathrm{CaO}$ and $\mathrm{CM}$ treatments was decreased by 88 , 72, 66 and $34 \%$ compared with CK treatment, respectively. During the whole incubation period, the difference of exchangeable acidity between treatments was significant. The soil exchangeable acidity of $\mathrm{Mg}(\mathrm{OH})_{2}$ treatment was stable below $0.5 \mathrm{cmol} / \mathrm{kg}$, which was the most effective one of reducing soil potential acid in four calcium-magnesium conditioners.

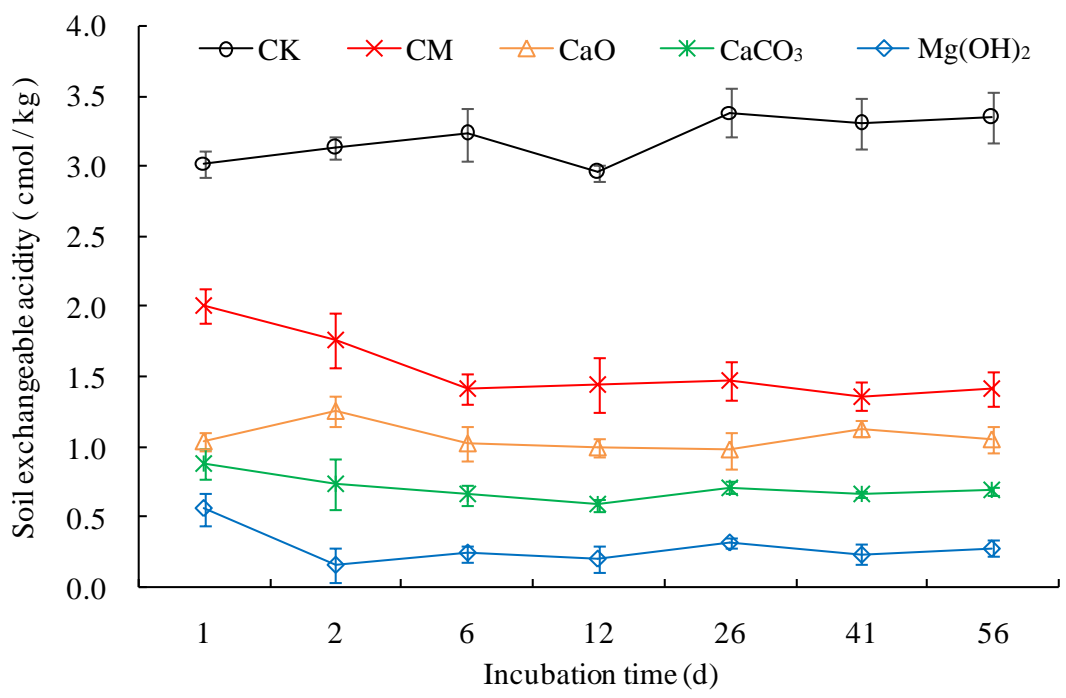

Fig. 2: Effects of different conditioners on soil exchangeable acid

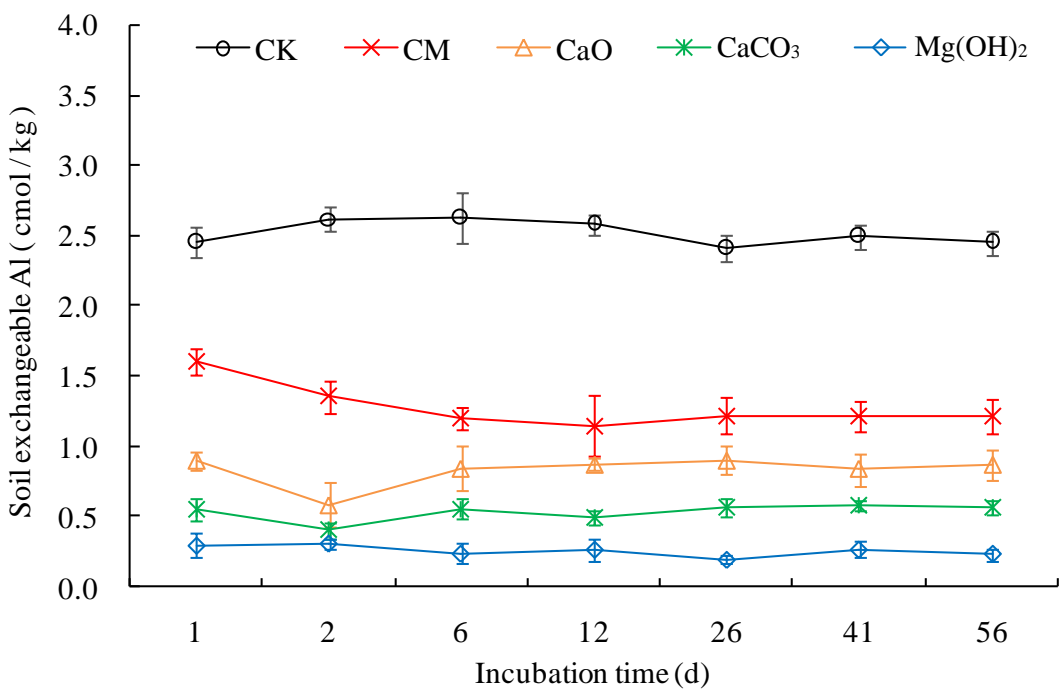

Fig. 3: Effects of different conditioners on soil exchangeable aluminum 
It can be seen from Fig. 3 that the application of calcium-magnesium conditioners can significantly reduce the content of soil exchangeable aluminum and alleviate the aluminum toxicity of acid soil to crops. In 56 days, the average content of soil exchangeable aluminum treated by $\mathrm{CM}, \mathrm{CaO}, \mathrm{CaCO}_{3}$ and $\mathrm{Mg}(\mathrm{OH})_{2}$ was 58, 71, 80 and $91 \%$ lower than that of $\mathrm{CK}$, respectively. The exchangeable aluminum content between the four conditioners is significantly different and the effect of reducing the exchangeable aluminum content is: $\mathrm{Mg}(\mathrm{OH})_{2}>\mathrm{CaCO}_{3}>\mathrm{CaO}>\mathrm{CM}$.

In summary, the calcium-magnesium conditioners can effectively reduce acid ions in acidic soils, thus reducing the adverse effects of soil acidification on crop growth. That was mainly because the alkaline component in the calcium-magnesium conditioner neutralizes the potential acid in the soil and supplements the calcium ions and magnesium ions that are lacking in the acidic soil. Considerable calcium and magnesium ions are absorbed by the soil colloid, replacing the original potential acid adsorbed in soil colloid, which can effectively reduce the content of soil exchangeable acid and exchangeable aluminum (Zhang et al., 2011). Considering the reduction of soil potential acid and active acid, $\mathrm{Mg}(\mathrm{OH})_{2}$ has a better effect on improving acid latosol. The possible reason is that $\mathrm{Mg}(\mathrm{OH})_{2}$ contains the most alkaline $\mathrm{OH}^{+}$. Once applied to the soil, it can directly neutralize the acid ions in the soil, while other calcium-magnesium conditioners contain less $\mathrm{OH}^{+}$ that may need to react with water in the soil to produce $\mathrm{OH}^{+}$to neutralize acid ions.

\section{Effects of Different Calcium-Magnesium Conditioners on Soil Organic Matter}

Soil organic matter is an important source of various nutrients in the soil. It can also increase the $\mathrm{pH}$ buffer capacity of the soil and affect the $\mathrm{pH}$ of soil. Otherwise, the $\mathrm{pH}$ can also affect the soil organic matter content (Curtin and Trolove, 2013). As shown in Table 2, after 56 days of incubation, the soil organic matter content of the other treatments decreased comparing with that of the initial soil $(21.12 \mathrm{~g} / \mathrm{kg})$ except for the $\mathrm{CM}$ treatment. This indicates that soil organic matter is mineralizing decomposed during soil incubation, so the content will be reduced. There is a difference in the degree of organic matter reduction between treatments. The more soil $\mathrm{pH}$ is increased, the less soil organic matter is decreased except for the CM, which are $\mathrm{Mg}(\mathrm{OH})_{2}<\mathrm{CaCO}_{3}<\mathrm{CaO}$ and $\mathrm{CK}$. This may be because when the soil $\mathrm{pH}$ is between 6.5 and 7.5 , it is suitable for the growth of most soil microorganisms and is beneficial to the mineralizing decomposition of organic matter (Curtin et al., 1998). When the $\mathrm{pH}$ of the strongly acidic soil increases, it is beneficial for the microorganism to decompose the organic matter. The results in Table 2 also show that the organic matter content of $\mathrm{CM}$ is the highest and there is almost no change comparing with the initial soil. This may be because soil with $\mathrm{CM}$ treating contains more soluble calcium and magnesium and high salinity inhibits the decomposition of soil organic matter by microorganisms.

\section{Effects of Different Calcium-Magnesium Conditioners on Soil EC and Water-Soluble Calcium and Magnesium}

Soil EC refers to the total amount of water-soluble salts contained in the soil. As can be seen from Fig. 4, the four calcium-magnesium conditioners significantly increased the EC of the soil compared to the CK treatment and the soil EC treated by CM was significantly higher than that of the other calciummagnesium conditioners. This is because CM contains more water-soluble calcium and magnesium, such as $\mathrm{MgCl}_{2}$ and $\mathrm{CaCl}_{2}$ and when it is put into the soil, it can significantly increase the total amount of watersoluble salts in the soil.

As can be seen from Table 3, the difference in soil water-soluble calcium and magnesium contents between treatments was significant $(\mathrm{p}<0.05)$. Compared with other treatments, $\mathrm{CM}$ treatment can significantly increase the content of soluble calcium and magnesium in soil, which is mainly related to the fact that CM contains more soluble calcium and magnesium ions. Compared with the $\mathrm{CK}$ control, $\mathrm{CaO}$ and $\mathrm{CaCO}_{3}$ treatment can significantly increase the content of soluble calcium, which is mainly because they contain more calcium ions and when it is put into the soil, some calcium ions are dissolved in the soil aqueous solution. $\operatorname{Mg}(\mathrm{OH})_{2}$ treatment can significantly increase the soluble magnesium content, which is related to the fact that $\mathrm{Mg}(\mathrm{OH})_{2}$ contains more magnesium ions.

\section{Effects of Different Calcium-Magnesium Conditioners on Soil Exchangeable Calcium and Magnesium}

Exchangeable calcium and magnesium ions are important base cations in the soil. Generally, the higher the base saturation, the lower the acid ion content in the soil and the higher the $\mathrm{pH}$ of soil. At the same time, exchangeable cations, such as exchangeable calcium and magnesium, are also closely related to the $\mathrm{pH}$ buffer capacity of the soil (Zhang et al., 2013). Therefore, it is of great significance to study the effects of calciummagnesium conditioners on the exchangeable calcium and magnesium content of soil and its effect on improving acid soil. From the average of the treatments on days 26 and 56 (Table 4), the application of the four calcium-magnesium conditioners significantly increased the soil exchangeable calcium content compared to $\mathrm{CK}$. Among them, $\mathrm{CM}$ and $\mathrm{CaCO}_{3}$ treatment increased more exchangeable calcium, followed by $\mathrm{CaO}$ and $\mathrm{Mg}(\mathrm{OH})_{2}$ 
treatment. The mean exchangeable calcium of $\mathrm{CM}$, $\mathrm{CaCO}_{3}, \mathrm{CaO}$ and $\mathrm{Mg}(\mathrm{OH})_{2}$ was increased by $87,85,58$ and $20 \%$, respectively compared to the mean exchangeable calcium of CK. The four calciummagnesium conditioners can increase the exchangeable calcium content to different extents, which is mainly related to the calcium ions with different forms and contents. The exchangeable calcium content of $\mathrm{CM}$,
$\mathrm{CaCO}_{3}, \mathrm{CaO}$ treatments were higher than those of $\mathrm{Mg}(\mathrm{OH})_{2}$ and $\mathrm{CK}$ showed that the conditioners with more calcium ions can increase more soil exchangeable calcium. The higher exchangeable calcium content in soil with $\mathrm{CM}$ treating compared to other calciumcontaining conditioners shows that the more conditioners contain available calcium $\left(60 \% \mathrm{CaCl}_{2}\right)$, the more soil exchangeable calcium is increased.

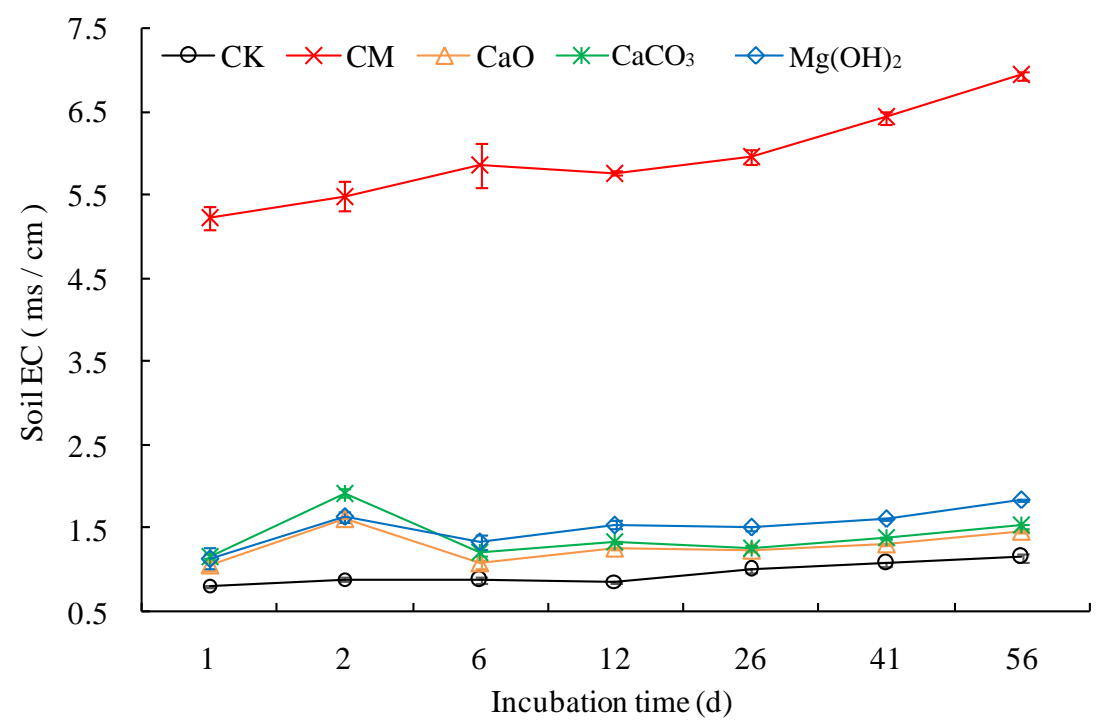

Fig. 4: Effects of different conditioners on soil EC

Table 2: Effects of different conditioners on soil organic matter $(\mathrm{g} / \mathrm{kg})$

\begin{tabular}{llllll}
\hline Treatments & $\mathrm{CK}$ & $\mathrm{CM}$ & $\mathrm{CaO}$ & $\mathrm{CaCO}_{3}$ & $\mathrm{Mg}(\mathrm{OH})_{2}$ \\
\hline Organic matter & $19.24 \pm 0.78 \mathrm{~b}$ & $20.63 \pm 0.00 \mathrm{a}$ & $19.78 \pm 0.75 \mathrm{ab}$ & $18.41 \pm 0.36 \mathrm{bc}$ & $17.82 \pm 0.97 \mathrm{c}$ \\
\hline
\end{tabular}

Note: The values are means \pm standard deviation, the data were analyzed as means of two consecutive experiments $(\mathrm{n}=12)$. Different small letters in the same line meant significant differences among conditioner treatments $(\mathrm{P}<0.05)$

Table 3: Effects of different conditioners on soluble $\mathrm{Ca}$ and $\mathrm{Mg}(\mathrm{cmol} / \mathrm{kg})$

\begin{tabular}{lllllll}
\hline Time & $\mathrm{Content}$ & $\mathrm{CK}$ & $\mathrm{CM}$ & $\mathrm{CaO}$ & $\mathrm{CaCO}_{3}$ & $\mathrm{Mg}(\mathrm{OH})_{2}$ \\
\hline $26(\mathrm{~d})$ & $\mathrm{Ca}$ & $0.15 \pm 0.02 \mathrm{~d}$ & $1.30 \pm 0.07 \mathrm{a}$ & $0.32 \pm 0.05 \mathrm{~b}$ & $0.35 \pm 0.02 \mathrm{~b}$ & $0.20 \pm 0.15 \mathrm{c}$ \\
& $\mathrm{Mg}$ & $0.20 \pm 0.04 \mathrm{c}$ & $1.58 \pm 0.07 \mathrm{a}$ & $0.10 \pm 0.01 \mathrm{~d}$ & $0.10 \pm 0.03 \mathrm{~d}$ & $0.45 \pm 0.03 \mathrm{~b}$ \\
$56(\mathrm{~d})$ & $\mathrm{Ca}$ & $0.18 \pm 0.02 \mathrm{e}$ & $1.29 \pm 0.05 \mathrm{a}$ & $0.35 \pm 0.03 \mathrm{c}$ & $0.41 \pm 0.03 \mathrm{~b}$ & $0.26 \pm 0.02 \mathrm{~d}$ \\
& $\mathrm{Mg}$ & $0.13 \pm 0.02 \mathrm{c}$ & $1.44 \pm 0.11 \mathrm{a}$ & $0.11 \pm 0.01 \mathrm{c}$ & $0.11 \pm 0.02 \mathrm{c}$ & $0.53 \pm 0.02 \mathrm{~b}$ \\
\multirow{2}{*}{ Mean } & $\mathrm{Ca}$ & $0.18 \pm 0.05 \mathrm{e}$ & $1.30 \pm 0.06 \mathrm{a}$ & $0.33 \pm 0.04 \mathrm{c}$ & $0.38 \pm 0.04 \mathrm{~b}$ & $0.23 \pm 0.03 \mathrm{~d}$ \\
& $\mathrm{Mg}$ & $0.18 \pm 0.05 \mathrm{c}$ & $1.51 \pm 0.12 \mathrm{a}$ & $0.10 \pm 0.01 \mathrm{~d}$ & $0.10 \pm 0.02 \mathrm{~d}$ & $0.48 \pm 0.04 \mathrm{~b}$ \\
\hline
\end{tabular}

Note: The values are means \pm standard deviation, the data were analyzed as means of two consecutive experiments $(\mathrm{n}=12)$. Different small letters in the same line meant significant differences among conditioner treatments $(\mathrm{P}<0.05)$

Table 4: Effects of different conditioners on exchangeable $\mathrm{Ca}$ and $\mathrm{Mg}(\mathrm{cmol} / \mathrm{kg})$

\begin{tabular}{lllllll}
\hline Time & Content & $\mathrm{CK}$ & $\mathrm{CM}$ & $\mathrm{CaO}$ & $\mathrm{CaCO}_{3}$ & $\mathrm{Mg}(\mathrm{OH})_{2}$ \\
\hline $26(\mathrm{~d})$ & $\mathrm{Ca}$ & $3.29 \pm 0.22 \mathrm{e}$ & $6.56 \pm 0.26 \mathrm{a}$ & $5.90 \pm 0.00 \mathrm{c}$ & $6.29 \pm 0.19 \mathrm{~b}$ & $4.22 \pm 0.09 \mathrm{~d}$ \\
& $\mathrm{Mg}$ & $1.61 \pm 0.00 \mathrm{~d}$ & $3.96 \pm 0.34 \mathrm{~b}$ & $2.16 \pm 0.14 \mathrm{c}$ & $1.85 \pm 0.27 \mathrm{~d}$ & $5.29 \pm 0.37 \mathrm{a}$ \\
$56(\mathrm{~d})$ & $\mathrm{Ca}$ & $3.22 \pm 0.14 \mathrm{~d}$ & $5.81 \pm 0.14 \mathrm{a}$ & $4.52 \pm 0.34 \mathrm{~b}$ & $5.86 \pm 0.09 \mathrm{a}$ & $3.75 \pm 0.00 \mathrm{c}$ \\
& $\mathrm{Mg}$ & $2.02 \pm 0.41 \mathrm{~b}$ & $5.29 \pm 0.58 \mathrm{a}$ & $2.90 \pm 0.46 \mathrm{~b}$ & $2.13 \pm 0.31 \mathrm{bc}$ & $5.70 \pm 0.49 \mathrm{a}$ \\
\multirow{3}{*}{ Mean } & $\mathrm{Ca}$ & $3.26 \pm 0.22 \mathrm{~d}$ & $6.18 \pm 0.44 \mathrm{a}$ & $5.21 \pm 0.75 \mathrm{~b}$ & $6.08 \pm 0.26 \mathrm{a}$ & $3.96 \pm 0.24 \mathrm{c}$ \\
& $\mathrm{Mg}$ & $1.82 \pm 0.59 \mathrm{c}$ & $4.61 \pm 0.84 \mathrm{~b}$ & $2.50 \pm 0.49 \mathrm{c}$ & $1.99 \pm 0.31 \mathrm{c}$ & $5.48 \pm 0.46 \mathrm{a}$ \\
\hline
\end{tabular}

Note: The values are means \pm standard deviation, the data were analyzed as means of two consecutive experiments $(\mathrm{n}=12)$. Different small letters in the same line meant significant differences among conditioner treatments $(\mathrm{P}<0.05)$ 
Table 5: Effects of different conditioners on soil $\mathrm{pH}$ buffer capacity

\begin{tabular}{|c|c|c|c|c|c|}
\hline \multirow[b]{2}{*}{ Time (d) } & \multicolumn{5}{|c|}{ pH buffer capacity (mmol/kg) } \\
\hline & $\mathrm{CK}$ & $\mathrm{CM}$ & $\mathrm{CaO}$ & $\mathrm{CaCO}_{3}$ & $\mathrm{Mg}(\mathrm{OH})_{2}$ \\
\hline 6 & $33.6 \pm 1.44 \mathrm{~b}$ & $36.4 \pm 0.00 \mathrm{a}$ & $31.2 \pm 0.69 \mathrm{c}$ & $30.8 \pm 0.20 \mathrm{c}$ & $29.9 \pm 0.39 c$ \\
\hline 12 & $31.5 \pm 0.35 \mathrm{~d}$ & $35.9 \pm 0.45 \mathrm{a}$ & $30.6 \pm 0.19 \mathrm{e}$ & $32.3 \pm 0.21 \mathrm{c}$ & $33.6 \pm 0.32 b$ \\
\hline 26 & $32.7 \pm 0.30 \mathrm{a}$ & $31.2 \pm 0.27 \mathrm{~b}$ & $32.7 \pm 0.30 \mathrm{a}$ & $28.0 \pm 0.33 \mathrm{~d}$ & $28.8 \pm 0.06 c$ \\
\hline 41 & $30.9 \pm 0.00 \mathrm{~b}$ & $33.3 \pm 0.00 \mathrm{a}$ & $30.7 \pm 0.14 b$ & $29.9 \pm 0.41 \mathrm{c}$ & $28.1 \pm 0.62 d$ \\
\hline 56 & $30.5 \pm 0.16 b$ & $32.2 \pm 0.29 \mathrm{a}$ & $28.6 \pm 0.46 \mathrm{~d}$ & $28.1 \pm 0.09 \mathrm{~d}$ & $29.7 \pm 0.25 c$ \\
\hline Mean & $31.6 \pm 1.00 \mathrm{~b}$ & $33.9 \pm 2.06 \mathrm{a}$ & $30.6 \pm 1.31 \mathrm{bc}$ & $29.8 \pm 1.68 \mathrm{c}$ & $29.8 \pm 1.91 c$ \\
\hline
\end{tabular}

Note: The values are means \pm standard deviation, the data were analyzed as means of two consecutive experiments $(\mathrm{n}=12)$. Different small letters in the same line meant significant differences among conditioner treatments $(\mathrm{P}<0.05)$

The results in Table 4 also show that $\mathrm{CM}$ and $\mathrm{Mg}(\mathrm{OH})_{2}$ significantly increase soil exchangeable magnesium content compared to $\mathrm{CK}$, while $\mathrm{CaCO}_{3}$ and $\mathrm{CaO}$ treatments are not significantly different from $\mathrm{CK}$. Among them, $\mathrm{Mg}(\mathrm{OH})_{2}$ treatment increased the most exchangeable magnesium, followed by $\mathrm{CM}$, which is mainly because $\mathrm{Mg}(\mathrm{OH})_{2}$ contained the most magnesium ions, followed by CM. When it was put into the soil, magnesium-containing conditioner can gradually release magnesium ions, which are absorbed by the soil colloid. It can be seen from the fact that the exchangeable magnesium content of day 56 is more than that of day 26.

\section{Effects of Different Calcium-Magnesium Conditioners on Soil pH Buffer Capacity}

The degree of soil acidification is related to soil $\mathrm{pH}$, acid ion input and buffer capacity of soil to acid. Among them, soil $\mathrm{pH}$ buffer capacity is the ability of soil to reduce soil acidification in response to external factors and soil $\mathrm{pH}$ buffer capacity can predict soil acidification process and its trend. The larger the $\mathrm{pH}$ buffer capacity is, the stronger soil buffer capacity for external acidity and the more stable $\mathrm{pH}$ in soil will be. The stable soil $\mathrm{pH}$ is conducive to the absorption and utilization of soil nutrient elements by plants and the maintenance of soil ecological functions (Augusto et al., 2017).

From the results of the average $\mathrm{pH}$ buffer capacity of each treatment within 56 days (Table 5), CM was significantly greater than other treatments and the soil buffer capacity was increased by $2.37 \mathrm{mmol} / \mathrm{kg}$ compared to $\mathrm{CK}$ treatment. The soil buffer capacity of $\mathrm{CaO}, \mathrm{CaCO}_{3}$ and $\mathrm{Mg}(\mathrm{OH})_{2}$ was decreased by $0.98,1.72$ and $1.73 \mathrm{mmol} / \mathrm{kg}$, respectively compared to $\mathrm{CK}$ treatment and the buffer capacities of $\mathrm{CaCO}_{3}$ and $\mathrm{Mg}(\mathrm{OH})_{2}$ were significantly lower than that of CK. This is mainly because the $\mathrm{pH}$ buffer capacity of soil is closely related to its $\mathrm{pH}$ buffer system and soil exchangeable cation, organic acid and organic matter are important parts of the soil acid-base buffer system (Nguyen, 2018). When $\mathrm{CaO}, \mathrm{CaCO}_{3}$ and $\mathrm{Mg}(\mathrm{OH})_{2}$ are added to the acidic soil, the alkaline component of the conditioner neutralizes the acidic materials in the soil, including low molecular organic acids in the soil. At the same time, the increase of $\mathrm{pH}$ promotes decomposition of soil organic matter (Table 2). The organic matter and organic acid are reduced and the functional groups with $\mathrm{pH}$ buffer capacity on them may also be destroyed, such as hydroxyl, carboxyl, phenolic hydroxyl group, alcoholic hydroxyl group (Curtin and Trolove, 2013). Therefore, the reduction of organic matter content and the destruction of functional groups on organic matter are the main reasons for the decrease of soil $\mathrm{pH}$ buffer capacity of $\mathrm{CaO}, \mathrm{CaCO}_{3}$ and $\mathrm{Mg}(\mathrm{OH})_{2}$ treatments. Although the $\mathrm{pH}$ of soil treated by $\mathrm{CM}$ is also increased, it has the lowest $\mathrm{pH}$ increase compared with other calcium-magnesium conditioners (Fig. 1), the highest organic matter content (Table 2) and significantly increased the contents of exchangeable calcium and magnesium in the soil (Table 4), i.e., exchangeable cation is supplemented. Therefore, CM can effectively improve the $\mathrm{pH}$ buffer capacity of the acid latosol.

It can be seen from Table 5 that with the prolongation of incubation time, the soil $\mathrm{pH}$ buffer capacity of each treatment has a different degree of decline, which may be related to the decrease of organic matter and organic acid and functional groups with $\mathrm{pH}$ buffer capacity were destructed led by organic matter decomposition during soil incubation.

\section{Conclusion}

Applications of $\mathrm{CM}, \mathrm{CaO}, \mathrm{CaCO}_{3}$ and $\mathrm{Mg}(\mathrm{OH})_{2}$ could rapidly increase the $\mathrm{pH}$ of acid latosol and significantly reduce the potential acid content in soil. During the whole incubation period, the soil $\mathrm{pH}$ of $\mathrm{Mg}(\mathrm{OH})_{2}$ was increased by more than one unit compared with $\mathrm{CK}$ treatment. The soil exchangeable acid of $\mathrm{Mg}(\mathrm{OH})_{2}, \mathrm{CaCO}_{3}, \mathrm{CaO}$ and $\mathrm{CM}$ was reduced by $88 \%$ and 72,66 and $34 \%$ comparing to $\mathrm{CK}$ treatment, respectively. The soil exchangeable aluminum decreased by $91,80,71$ and $58 \%$, respectively. Among them, $\mathrm{Mg}(\mathrm{OH})_{2}$ has the best effect on reducing active acid and potential acid in latosol.

The application of these four calcium-magnesium conditioners can significantly increase the content of soluble and exchangeable calcium in soil compared with $\mathrm{CK}$ treatment. The average exchangeable calcium of $\mathrm{CM}$, 
$\mathrm{CaCO}_{3}, \mathrm{CaO}$ and $\mathrm{Mg}(\mathrm{OH})_{2}$ was increased by $87,85,58$ and $20 \%$, respectively. Application of $\mathrm{CM}$ and $\mathrm{Mg}(\mathrm{OH})_{2}$ significantly increased soil soluble and exchangeable magnesium content, while $\mathrm{CaCO}_{3}$ and $\mathrm{CaO}$ treatments' effects on exchangeable magnesium were not significantly different from $\mathrm{CK}$ treatments and $\mathrm{Mg}(\mathrm{OH}) 2$ treatment increased the most exchangeable magnesium among them.

The soil $\mathrm{pH}$ buffer capacity of $\mathrm{CM}$ is significantly higher than that of other treatments, which has the best effect on improving the $\mathrm{pH}$ buffer capacity of latosol, while the soil pH buffer capacity of $\mathrm{CaCO}_{3}$ and $\mathrm{Mg}(\mathrm{OH})_{2}$ are significantly less than that of $\mathrm{CK} . \mathrm{CaO}$ and $\mathrm{CK}$ have no significant differences.

Therefore, this paper proposes to improve the acid latosol by applying calcareous conditioner with more water-soluble calcium and magnesium ions and magnesium hydroxide, which can effectively reduce the acid ion content in the soil and improve the $\mathrm{pH}$ buffer capacity of the soil. But the paper did not involve the optimal percentage of the weight of each component $\left(\mathrm{Mg}(\mathrm{OH})_{2}, \mathrm{Ca}(\mathrm{OH})_{2}, \mathrm{MgCl}_{2}, \mathrm{CaCl}_{2}\right.$, ) in $\mathrm{CM}$, which is the research field in the future.

\section{Acknowledgement}

This work was supported by Innovation and Entrepreneurship Education Reform Project of Guangdong Colleges (2018A012404), Innovating and Strengthening Colleges Project of Guangdong (2018KQNCX104), Scientific Research Foundation for Ph.D of Guangdong Ocean University (E15038), Students' Innovation and Entrepreneurship Training Program of Guangdong Ocean University (CXXL2019288).

\section{Author's Contributions}

Jin Li and Yingbin Xue: Designed and performed the experiments, analyzed the data and prepared the paper. Both authors contributed equally to this work.

Minzhong Chen: Participated to collect the materials related to the experiment.

Huirong Su and Zhengwei Wu: Collection and assembly of data, data analysis and interpretation.

Tingting Duan: Research concept and design, final approval of article.

\section{Ethics}

Authors should address any ethical issues that may arise after the publication of this manuscript.

\section{References}

Antonangelo, J. A., Ferrari Neto, J., Crusciol, C. A. C., \& Alleoni, L. R. F. (2017). Lime and calciummagnesium silicate in the ionic speciation of an Oxisol. Scientia Agricola, 74(4), 317-333.
Augusto, L., Achat, D. L., Jonard, M., Vidal, D., \& Ringeval, B. (2017). Soil parent material-a major driver of plant nutrient limitations in terrestrial ecosystems. Global change biology, 23(9), 3808-3824.

Bao, S. D. (2010). Analysis of agrochemical soil. Beijing: China Agricultural Press.

Curtin, D., \& Trolove, S. (2013). Predicting pH buffering capacity of New Zealand soils from organic matter content and mineral characteristics. Soil Research, 51(6), 494-502.

Curtin, D., Campbell, C. A., \& Jalil, A. (1998). Effects of acidity on mineralization: $\mathrm{pH}$-dependence of organic matter mineralization in weakly acidic soils. Soil Biology and Biochemistry, 30(1), 57-64.

Elisa, A. A., Ninomiya, S., Shamshuddin, J., \& Roslan, I. (2015). Alleviating aluminium toxicity on an acid sulphate soils in Peninsular Malaysia with application of calcium silicate. Solid Earth Discussions, 7(4), 2903-2926.

Fu, X., Shao, M., Wei, X., \& Horton, R. (2010). Soil organic carbon and total nitrogen as affected by vegetation types in Northern Loess Plateau of China. Geoderma, 155(1-2), 31-35.

Guo, J. H., Liu, X. J., Zhang, Y., Shen, J. L., Han, W. X., Zhang, W. F., ... \& Zhang, F. S. (2010). Significant acidification in major Chinese croplands. science, 327(5968), 1008-1010.

Illera, V., Garrido, F., Serrano, S., \& García-González, M. T. (2004). Immobilization of the heavy metals $\mathrm{Cd}, \mathrm{Cu}$ and $\mathrm{Pb}$ in an acid soil amended with gypsum-and lime-rich industrial by-products. European Journal of Soil Science, 55(1), 135-145.

Li, J., Duan, T. T., \& Zheng, C. (2019). An Ionexchange Based Approach for Production of Soil Conditioner with Magnesium Extracted from Seawater. Revista de la Facultad de Agronomia de la Universidad del Zulia, 36(3), 716-725.

Lollato, R. P., Edwards, J. T., \& Zhang, H. (2013). Effect of alternative soil acidity amelioration strategies on soil $\mathrm{pH}$ distribution and wheat agronomic response. Soil Science Society of America Journal, 77(5), 1831-1841.

Lu, X., Mao, Q., Gilliam, F. S., Luo, Y., \& Mo, J. (2014). Nitrogen deposition contributes to soil acidification in tropical ecosystems. Global change biology, 20(12), 3790-3801.

Nguyen, T. (2018). The $\mathrm{pH}$ buffering capacity of Acrisols under cassava production in Southeastern Vietnam, Chau Thanh district. Soil Use and Management, 34(4), 554-562.

Seeger, T. S., Muller, E. I., Mesko, M. F., \& Duarte, F. A. (2019). Magnesium and calcium determination in desalted crude oil by direct sampling graphite furnace atomic absorption spectrometry. Fuel, 236, 1483-1488. 
Takeda, N., Hashihama, F., \& Kanda, J. (2020). Automated colorimetric determination of nanomolar urea in seawater by gas-segmented continuous flow analysis using a liquid waveguide capillary cell. Talanta, 208, 120371.

Teutscherova, N., Vazquez, E., Masaguer, A., Navas, M., Scow, K. M., Schmidt, R., \& Benito, M. (2017). Comparison of lime-and biochar-mediated $\mathrm{pH}$ changes in nitrification and ammonia oxidizers in degraded acid soil. Biology and Fertility of Soils, 53(7), 811-821.
Zhang, C., Wu, P., Tang, C., Tao, X., Han, Z., Sun, J., \& Liu, H. (2013). The study of soil acidification of paddy field influenced by acid mine drainage. Environmental earth sciences, 70(7), 2931-2940.

Zhang, F., Cui, Z., Fan, M., Zhang, W., Chen, X., \& Jiang, R. (2011). Integrated soil-crop system management: reducing environmental risk while increasing crop productivity and improving nutrient use efficiency in China. Journal of Environmental Quality, 40(4), 1051-1057. 